症 例

\title{
早期胃癌症例の検討
}

久留米大学第 1 外科（主任：掛川暉夫）

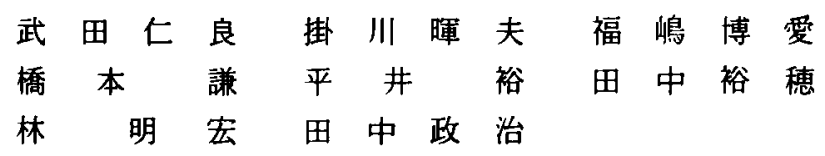

\section{A CLINICAL STUDY OF EARLY GASTRIC CANCER}

Jinryo TAKEDA, Teruo KAKEGAWA, Hironaru FUKUSHIMA, Ken HASHIMOTO,

You HIRAI, Takaho TANAKA, Akihiro HAYASHI and Masaharu TANAKA 1st Department of Surgery, Kurume University School of Medicine

(Director : Prof. Teruo KAKEGAWA)

$\mathrm{X}$ 線，内視鏡，生検検查の進歩により胃癌の早期発見が可能になって来た，教室の22 年間の早期胃癌は297例で切除総数の $20.5 \%$ に相当する.

早期胃癌の肉眼病型では陥凹型が $68.0 \%$ と最も多く隆起型は $20.2 \%$. 混合型 $10.8 \%$. 平坦型 $1.0 \%$ でる。

主たる占居部位と組織学的深達度ではC $\mathrm{C}$ 癌10例, $\mathrm{sm}$ 癌18例と $\mathrm{sm}$ に多く，Mでは $\mathrm{m}$ 癌91例, sm 癌80例, $\mathrm{A} て ゙ は \mathrm{~m}$ 癌48例, $\mathrm{sm}$ 癌 50 例で, 全体では $\mathrm{m}$ 癌 149 例, $\mathrm{sm}$ 癌148例 である。

リンバ節転移陽性例は297例中41例 (13.8\%) で， $\mathrm{m}$ 癌では6.0\%， sm 癌では21.6\%で ある.癌の大きさとリンバ節転移との関係をみると, $\mathrm{m}$ 癌 $\mathrm{sm}$ 癌とも大きくなるにつれて 転移率は上昇し， $6.1 \mathrm{~cm}$ 以上ではm癌 $18.2 \%, \mathrm{sm}$ 癌 $41.7 \%$ である.

郭清リンバ節からみると 1 群の転移率は $10.8 \% ， 2$ 群は $2.4 \%$ で $3 ， 4$ 群は 1 例ずつで ある.

はじめに

$\mathrm{X}$ 線.内視鏡, 生検検査の進歩により近年胃癌の早 期発見が可能となり $5 \mathrm{~mm}$ 以下の殿小胃癌の報告も多 数みられるよらになってきた。 さらに集団検診の普及 により, 各施設とも早期胃癌の頻度が進行癌に比し増 加している.

早期胃癌は早期食道癌と異なりその定義にリンパ節 転移の有無は関係なく，一般に予後良好であるが，再 発例もみられリンパ節転移陽性も決して少なくない。 そこで今回はリンバ節転移の状況を中心に若干の考察 を加えてみた。

\section{対象症例}

久留米大学医学部第 1 外科における昭和 34 年より昭 和55年までの過去22年間の重裉癌をのぞく胃癌切除総
数は1450例で, その5ち早期癌は297例, 進行癌は1153 例で，早期胃癌は切除総数の $20.5 \%$ に相当する. 男女 比は約 $2 ： 1$ と男性に多く60葴代が最b多く次いて40 歳代, 50歳代である（図 1 ).

早期胃癌の肉眼病型ではII c, II c+IIIなどの陥凹型 かi297例中202例 $(68.0 \%)$ と最む多く，I 型，II a な ど隆起型が60例 $(20.2 \%)$ ，II a + II c, II c+II a など 混合型が32例 $(10.8 \%)$, 平坦型は 3 例 (1.0\%) となっ ている(图 2).

早期胃癌の癌病巣の長径は $0.5 \mathrm{~cm}$ 以下の数小癌 3 例, $0.5 \sim 1 \mathrm{~cm} の$ 小胃癌27例, $1.1 \sim 2.0 \mathrm{~cm} 67$ 例,

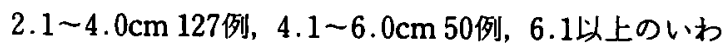
ゆる表層拡大23例でこの型は早期胃癌の $8 \%$ にみれ た（図 3 ). 


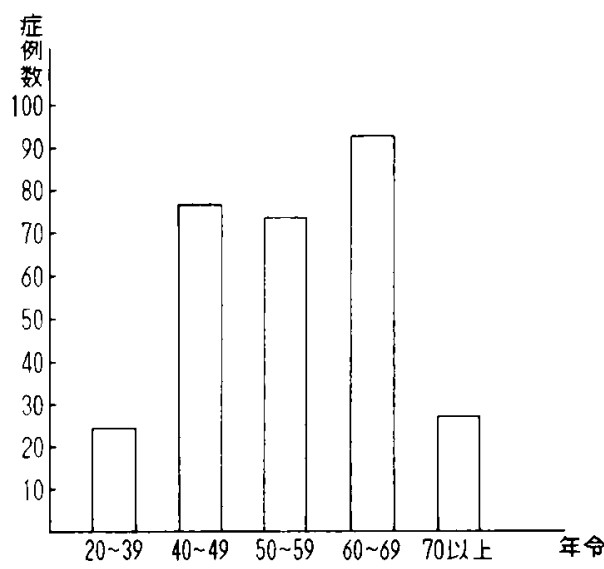

図 1 早期胃癌の年黹別頻度

\begin{tabular}{|c|c|c|c|}
\hline \multirow{3}{*}{ 隆起型 } & I 型 & 28 & \multirow{3}{*}{$60(20.2 \%)$} \\
\hline & II $\mathrm{a}$ & 26 & \\
\hline & その他 & 6 & \\
\hline \multirow{2}{*}{ 混合型 } & $\Pi \mathbf{a}+\mathbb{I} \mathrm{c}$ & 22 & \multirow{2}{*}{$32(10.8 \%)$} \\
\hline & $\mathbb{I I} c+\mathbb{I} a$ & 10 & \\
\hline \multirow{4}{*}{ 陥凹型 } & II $c$ & 132 & \multirow{4}{*}{202 (68.0\%) } \\
\hline & II c + III & 59 & \\
\hline & $\mathbb{I I}$ & 9 & \\
\hline & $\mathbb{I I}+\mathbb{I} \mathrm{c}$ & 2 & \\
\hline 平担型 & II $\mathbf{b}$ & 3 & $3(196)$ \\
\hline
\end{tabular}

図 2 早期胃癌の肉眼型（昭和 34 55 年）

\begin{tabular}{r|c}
\hline $6.1 \mathrm{~cm}-$ & 23 \\
\hline $4.1 \mathrm{~cm} \sim 6.0 \mathrm{~cm}$ & 50 \\
\hline $2.1 \mathrm{~cm} \sim 4.0 \mathrm{~cm}$ & 127 \\
\hline $1.1 \mathrm{~cm}-2.0 \mathrm{~cm}$ & 67 \\
\hline $0.6 \mathrm{~cm}-1.0 \mathrm{~cm}$ & 27 \\
\hline$-0.5 \mathrm{~cm}$ & 3 \\
\hline
\end{tabular}

图3早期胃癌の癌病巣の長径（昭和34年〜 55年）

早期胃癌の部位別頻度を主たる占居部位からみると 胃上部 (C) 28例 (9.4\%)，胃中部 (M) 17例 (57.6\%) 胃下部(A) 98例 (33\%) でMが最も多くCは少ない。 周在性では各領域とも小弯に好発し次いで前後壁に多 く大弯が最子少ない(図4).

主たる占居部位と組織学的深達度ではCは28例中m 癌10例, $\mathrm{sm}$ 癌18例で $\mathrm{sm}$ に多く, Mではm癌91例, sm 癌80例で，Aではm癌48例, sm 癌50例と AおよびMで

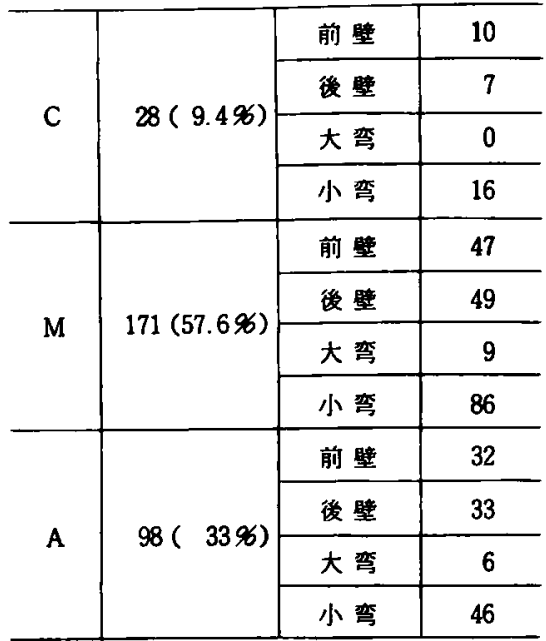

图 4 早期胃癌の占居部位（昭和 $34 \sim 55$ 年）

\begin{tabular}{c|c|c}
\hline 占拠部位 & $\mathrm{m}$ & $\mathrm{sm}$ \\
\hline $\mathrm{C}(28)$ & $10(35.7 \%)$ & $18(64.3 \%)$ \\
\hline $\mathrm{M}(171)$ & $91(53.2 \%)$ & $80(46.8 \%)$ \\
\hline $\mathrm{A}(98)$ & $48(49.0 \%)$ & $50(51.0 \%)$ \\
\hline
\end{tabular}

图 5 占居部位と組琽学的深達度

は深達度別症例数に大差がない，全体ではm癌149例， $\mathrm{sm}$ 癌148例とほぼ同数となっている（図 5).

$$
\text { リンパ節転移 }
$$

リンパ節転移陽性例は297例中41例（13.8\%）で，m 癌では149例中 9 例 $(6.0 \%) . \mathrm{sm}$ 癌では148例中32例 (21.6\%)で当然のこと乍ら sm 癌にその頻度が高い. その転移程度をみると $\left.\mathrm{n}_{1}(+)\right)$ は $\mathrm{m}$ 癌 $\mathrm{sm}$ 癌で32例 $(10.8 \%), \mathrm{n}_{2}(+)$ は $\mathrm{m}$ 癌 2 例, $\mathrm{sm}$ 癌 5 例で計 7 例

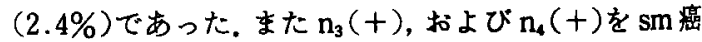
に1例ずつ経験している.なお大部分が一群までのり ンバ節転移陽性例であるが，二群ばかりでなく三群四 群までの転移陽性例む経殹しており充分な注意が必要 である(图6).

主たる占居部位とリンハ節転移陽性との関保をみる と，Cで28例中 1 例 $(3.5 \%) . \mathrm{M} て ゙ は 171$ 例中20例 (11.7\%)，Aでは98例中20例（20.4\%）でAのリン: 節転移頻度が最も高い。なお前述した $\mathrm{n}_{3}(+)$ 性 $\mathrm{A}$ 領 域， $n_{4}(+)$ は領域の症例であった。

リンバ節転移陽性例の癌占拠部位とリンバ節 number との関係をみると、Cでは(3)小弯リンバ節, Mで㤌

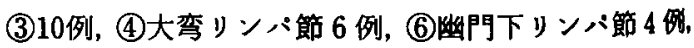




\begin{tabular}{|c|c|c|c|c|c|}
\hline 深達度 & $\mathrm{n}_{1}(+)$ & $\mathrm{n}_{2}(+)$ & $n_{3}(+)$ & $n_{4}(+)$ & 軽移率 \\
\hline $\mathbf{m}$ & 7 & 2 & 0 & 0 & $\frac{9}{149}(6.096)$ \\
\hline sm & 25 & 5 & 1 & 1 & $\frac{32}{148}(21.696)$ \\
\hline 合計 & $\begin{array}{c}32 \\
(10.8 \%)\end{array}$ & $\begin{array}{c}7 \\
(2.4 \%)\end{array}$ & $(0.3 \%)$ & $\stackrel{1}{(0.3 \%)}$ & $\frac{41}{297}(13.8 \%)$ \\
\hline
\end{tabular}

图6 早期胃癌の深達度別リンパ節転移率

\begin{tabular}{r|c|c}
\hline \multirow{2}{*}{ 長怿の大きさ } & $\mathrm{m}$ & $\mathrm{sm}$ \\
\cline { 2 - 3 } & $\mathrm{n}(+)$ 例/症例数 & $\mathrm{n}(+)$ 例/症例数 \\
\hline$\sim 0.5 \mathrm{~cm}$ & $0 / 3(0 \%)$ & $0 / 0(0 \%)$ \\
\hline $0.6 \sim 1.0 \mathrm{~cm}$ & $0 / 15(0 \%)$ & $2 / 12(16.7 \%)$ \\
\hline $1.1 \sim 2.0 \mathrm{~cm}$ & $2 / 40(5 \%)$ & $2 / 27(7.4 \%)$ \\
\hline $2.1 \sim 4.0 \mathrm{~cm}$ & $2 / 59(3.4 \%)$ & $17 / 68(25 \%)$ \\
\hline $4.1 \sim 6.0 \mathrm{~cm}$ & $3 / 21(14.3 \%)$ & $6 / 29(20.7 \%)$ \\
\hline $6.1 \mathrm{~cm} \sim$ & $2 / 11(18.2 \%)$ & $5 / 12(41.7 \%)$ \\
\hline 合 計 & $\frac{9}{149}(6.0 \%)$ & $\frac{32}{148}(21.7 \%)$ \\
\hline
\end{tabular}

図7早期胃病病果の長径とリンパ節転移(昭和 $34 \sim 55$ 年)

(7)左胃動脈幹リンパ節および(8)総肝動脈幹リンパ節が 各々 3 例, (1)右噴門リンパ節 2 例で $\mathrm{n}_{4}(+)$ は(16)大動脈 周曲リンバ節であった。 またAでは(6) 7 例と最も多く (3)(4)各 4 例, (7) 3 例, (5)(8)各 1 例, $\mathrm{n}_{3}$ (+)は(12)であった.

癌の大きさとリンパ節転移との関係をみると, $1 \mathrm{~cm}$ 未满ではm癌は18例中 $\mathrm{n}(+)$ 例はないが, sm 癌では12 例中 2 例 (16.7\%)がn(+)であった，図 7 に示す如く $\mathrm{m}$ 癌, $\mathrm{sm}$ 癌とも大きくなるにつれて転移率は上昇し $6.1 \mathrm{~cm}$ 以上ではm癌 11 例中 2 例 $(18.2 ;), \mathrm{sm}$ 癌では 12 例中 5 例1 $(41.7 \%)$ と高頻度にみられた。

\section{切除と再建}

幽門側切除で, Billroth I 法（以下 B-I）による再 建は268例中100例 (37.3\%) Billroth II 法 (以下 B-II) は268例中168例 $(72.7 \%)$ でB-IIが多い。牫胃が大き い場合に拈いてのみ B-Iを行なってきたが最近では 来るだけ一般に生理的再建コースと云われる B-Iを 行なっている、㫣た噴門切除例はわずか10例であるが これはC 領域の早期胃癌が少ないのが主な原因で，胃 全摘を施行した19例は病巣の大きなものが主な対象と なっている。

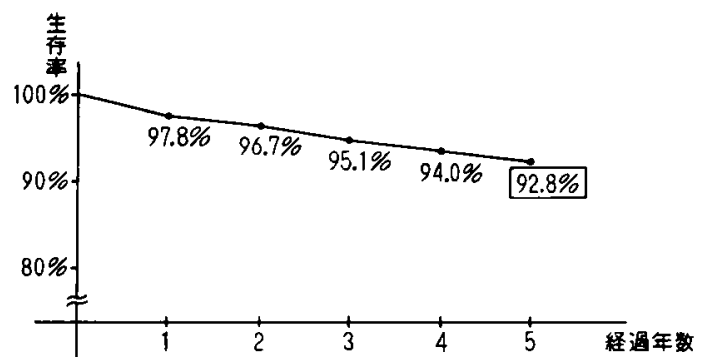

图 8-1) 早期胃癌の 5 年生存率（昭和 34 -50 年）

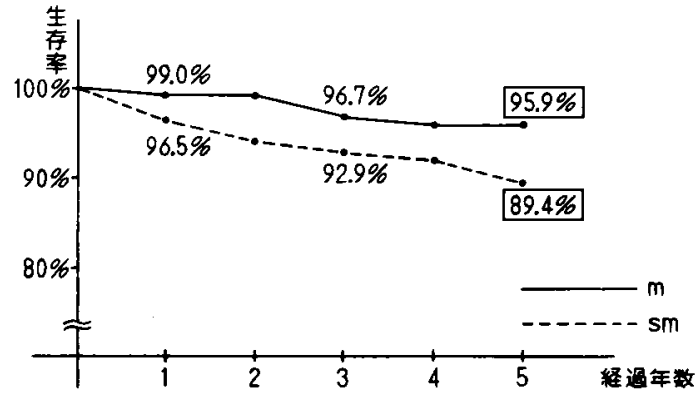

図8-2）早期胃瘦の深達度別 5 年生存率（昭和 $34 \sim 50$ 年)

\section{予啳}

昭和34年より50年までの 17 年間の早期胃癌切除例は 183例で，このらち170例が在存した。10例が死因不明 および消息不明で残りの 3 例が癌死であった。死因お よび消息不明症例を癌死とみなし，明らかな他病死を 除外した粗生存率でみると，深達度別で 5 年生存率は $\mathrm{m}$ 癌で $95.9 \%, \mathrm{sm}$ 癌で89.4\%で total は92.8\%の 5 生 率で図 8 はその年度別推移を示している(図 8-1，8． 2 ).

stage 別5年生存率では stage I 165例中157例(94. $5 \%$ ) stage II 12例中 9 例 (75\%), stage III 3 例中 3 例 (100\%), stage IV 2 例中 1 例（50\%）となっている. 
ow $(+)$ 症例は297例中 3 例で 1 例は 5 年 7 力 月で死 亡, 残り 2 例は 8 年目, 5 年目の現在生存中である。 なお 8 年生存中の 1 例は術後 7 年目に再手術にて胃全 摘を行なったがその時点でも早期癌であった。

\section{考案}

胃癌症例での早期胃癌の占める割合は諸家の報告で も近年增加が 田 ${ }^{3} 38 \%$ となっている. 昭和43年での教室の集計では 切除胃癌稳数 632 例中早期癌は 54 例で $8.5 \%$ と少なく, 昭和34年より55年では切除胃癌総数1450例中 297 例之 $20.5 \%$ で年度によっては $30 \%$ を越し近年増加してい る.

早期胃癌す男性に多く男女比は約 2：1 とほほ一定 している2゙3). 肉眼型ではII c を中心とする宿凹型が多 く，隆起型は一般に16２0\%で数室でのそれは $20.2 \%$ である。

占居部位ではA 領域に多いという報告やM領域に多 いとする報告もあるが，症例の多い広田 ${ }^{31}$ の1000例の 報告ではA $30.2 \%$ ，M $57.8 \% \mathrm{C} 12.0 \%$ と M が多い. 教室でもMが多く, A $30.2 \%, M 57.5 \%, C 9.3 \%$ と諸家の報告と同様にCが最も少ない。

年龄は50歳, 60 歳代に多いが教室例では60歳代が最 b多い.

深達度別頻度では神前")はm癌292例，sm 癌302例， 広田 ${ }^{3)}$ は $\mathrm{m}$ 癌525例, $\mathrm{sm}$ 癌475例と報告しているが教室 ではm癌149例, $\mathrm{sm}$ 癌148例となっている.今後 $\mathrm{m}$ 癌が 増加するものと考えている。

早期胃癌のリンパ節転移陽性頻度は15\%前後で大 森 ${ }^{6)}$ 集計では2362例中341例 (14.4\%) である。教室 例は297例中41例 $(13.8 \%)$ でm癌6.0\%， sm 癌 $21.6 \%$ と決して低率ではない，しかし諸家の報告でも転移は 大部分が一群リンパ節までの $\mathrm{n}_{1}(+)$ 例で, 教室でる $\mathrm{n}_{1}$ (十)10.8\%， $\mathrm{n}_{2}(+) 2.4 \%$ あったことより $\mathrm{R}_{2}$ の手術 ではぼ满足するすのむ考えるが， $n_{3}(+)$ 扰よび $n_{4}(+)$ 例もあり十分な注意は必要である，占居部位とリンパ 節転移状況でみると，C領域はNo (1)，Mでは(3)(4)，A では(3)(4)(6)などの一群リンパ節での転移性が多いと一 般に云われている. また二群のリンハ節では(7)(8)が 高率であるといわれるが私どすの症例では(7)(8)で(9) はみられずこの一因として必ずしも徹底した郭清が行 なわれていなかったことる若干影響しているものと考 えている．石井21は第三群では(12)(14)注意すべきで症 例によっては $\mathrm{R}_{3}$ の手術が必要であると報告している。
癌巣の大きさとリンパ節転移との関俰では一般に長 径が大きくなるにつれて転移の頻度が高く，教空例で も $\mathrm{m}$ 癌で $1 \mathrm{~cm}$ 末满に $\mathrm{n}(+)$ はないが, $6.1 \mathrm{~cm}$ 以上では $18.2 \%$ が $\mathrm{n}(+)$ であり $\mathrm{sm}$ 癌では $1 \mathrm{~cm}$ 末满です $16.7 \% ， 6.1 \mathrm{~cm}$ 以上では $41.7 \%$ と高率である.

肉眼病型とリンハ節との関係では隆起型か陥凹型に 比ベリンバ節転移が高率で, 特に sm の隆起型ではそ の頻度が高い上らである。井ロ”はPen A型では隆起 型が多く特にリンパ節転移が高率であると報告してい る.

早期胃癌の遠隔成績は諸家の報告では，m癌で約 95\%, sm 癌で $90 \%$ とされて扣り教室です $\mathrm{m}$ 癌 $95.9 \%$, sm 癌89.4\%であった。

幽門側切除の際，B-Iでの再建がより生理的であろ らが, 残胃の小さい場合では His 角が術後鈍化する ことや, 裂孔へルニフのある場合での食道への逆流が みられることるあり症例によってはB-II法での再建 が良いものと考えている。

\section{七す $\boldsymbol{U}$}

早期胃癌297例につきリンバ節転移について検討し た。深達度別ではm癌6.0\%, sm 癌， $21.6 \%$ で特に長 径の長いすのに転移陽性が多くみられた。

\section{文 献}

1）古賀成昌, 岸本宏之: 胃癌の遠隔成嘖術後 5 年10 年生存率からみた治療成績向上因子の分析, 日外 会誌, $78: 860-863,1977$.

2）石井俊世,三浦敏夫, 原田達郎他 : 教室における 早期胃癌手術症例の検討一特にリンハ節転移を中 心に一，日消外会誌，14:39-44，1981。

3）広田映五, 海上雅光, 板橋正幸他 : 早期胃癌の病 理：病理形態之予後, 消化器外科, $4: 295-300$, 1981.

4）脇坂順一，樺木野修郎，福久由光他：早期胃癌の 病理学的検討, 外科診療, $10: 598-606,1969$.

5）神前五郎, 岩永 用, 古河 洋: 早期胃癌の治餈 と遠隔成樍，外科治療，39：674-678，1978。

6) 大森幸夫, 本田一郎, 西沢 護: 術前診断と開腹 所見からみた早期胃癌の治療方針，消化器外科， $4: 289-293,1981$.

7）井口深, 杉町圭蔵：早期胃癌の進展と再発形成, 消化器外科, $4: 319-324,1981$.

8）遠藤篤：胃切除後の食道内逆流一とくにビル ロートI法胃要全摘術後の障害について一, 日消 外会誌, $11: 188-197,1978$. 